\title{
Interleukin-11 Promotes T Cell Polarization and Prevents Acute Graft-Versus-Host Disease after Allogeneic Bone Marrow Transplantation
}

\author{
Geoffrey R. Hill, ${ }^{\star}$ Kenneth R. Cooke, ${ }^{\star}$ Takanori Teshima, ${ }^{\star}$ James M. Crawford, ${ }^{\ddagger}$ James C. Keith, Jr., ${ }^{\S}$ Yani S. Brinson, \\ David Bungard, ${ }^{*}$ and James L.M. Ferrara* \\ *Department of Pediatric Oncology, Dana Farber Cancer Institute, Harvard Medical School, Boston, Massachusetts 02115; ${ }^{\ddagger}$ Department \\ of Pathology, Yale University School of Medicine, New Haven, Connecticut 06520-8023; and ${ }^{\S}$ Department of Preclinical Research and \\ Development, Genetics Institute, Inc., Andover, Massachusetts 01810
}

\begin{abstract}
Administration of IL-11 prevented lethal graft-versus-host disease (GVHD) in a murine bone marrow transplant $(\mathrm{BMT})$ model (B6 $\rightarrow$ B6D2F1) across MHC and minor $\mathrm{H}$ antigen barriers (survival at day 50: 90 vs $20 \%, P<0.001$ ). Surpisingly, IL-11 administration polarized the donor $\mathrm{T}$ cell cytokine responses to host antigen after BMT with a $50 \%$ reduction in IFN $\gamma$ and IL-2 secretion and a 10-fold increase in IL-4. This polarization of T cell responses was associated with reduced IFN $\gamma$ serum levels and decreased IL-12 production in mixed lymphocyte cultures (MLC). In addition, IL-11 prevented small bowel damage and reduced serum endotoxin levels by $80 \%$. Treatment with IL-11 also reduced $\mathrm{TNF} \alpha$ serum levels and suppressed TNF $\alpha$ secretion by macrophages to LPS stimulation in vitro. IL-11 thus decreased GVHD morbidity and mortality by three mechanisms: (a) polarization of donor $\mathrm{T}$ cells; $(b)$ protection of the small bowel; and (c) suppression of inflammatory cytokines such as TNF $\alpha$. We conclude that brief treatment with IL-11 may represent a novel strategy to prevent $T$ cell-mediated inflammatory processes such as GVHD. (J. Clin. Invest. 1998. 102:115-123.) Key words: total body irradiation - gastrointestinal tract $\bullet$ endotoxin $\bullet$ inflammatory cytokines $\bullet T$ cells
\end{abstract}

\section{Introduction}

IL-11 is a member of the IL- 6 cytokine family that is produced by a variety of tissues including the central nervous system, thymus, lung, bone, skin, and connective tissue and has pleotropic effects (1). IL-11 stimulates megakaryopoesis and accelerates neutrophil recovery after myelosuppressive therapy (2-4). IL-11 also possesses potent antiinflammatory effects by virtue of its ability to inhibit nuclear translocation of nuclear factor- $\kappa \mathrm{B}(\mathrm{NF}-\kappa \mathrm{B})^{1}(5,6)$. Preclinical studies have demonstrated the efficacy of IL-11 in treating inflammatory disorders including radiation-induced lung damage (7), inflammatory

Address correspondence to James L.M. Ferrara, Dana Farber Cancer Institute, Rm. M628, 44 Binney Street, Boston, MA 02115. Phone: 617-632-3528; FAX: 617-632-2085; E-mail: james_ferrara@dfci. harvard.edu

Received for publication 17 February 1998 and accepted in revised form 21 April 1998.

J. Clin. Invest.

(C) The American Society for Clinical Investigation, Inc. 0021-9738/98/07/0115/09 \$2.00

Volume 102, Number 1, July 1998, 115-123

http://www.jci.org bowel disease (8), and sepsis (9). In addition, IL-11 downregulates IL-12 production by macrophages (10), which suggests that IL-11 may also modulate T cell-mediated inflammation.

Acute GVHD is the most common complication of allogeneic BMT and offers a unique perspective from which to study the effects of IL-11 on both inflammatory and T cell effector functions in vivo. During acute GVHD, cytokine dysregulation occurs as a consequence of synergistic interactions between cells of both myeloid and lymphoid lineages (11). T cells present in the donor inoculum encounter alloantigen and, in the presence of IL-12, secrete the Th1 cytokines IFN $\gamma$ and IL-2 (12). IFN $\gamma$ primes monocytes and macrophages to secrete large quantities of inflammatory cytokines after stimulation by LPS (13). Together with NK and T cells, these cytokines mediate GVHD target organ damage (14).

Given its antiinflammatory properties, we investigated the use of IL-11 in a well-characterized mouse model of GVHD directed against MHC and minor histocompatibility antigens. Our results show that IL-11 reduces small bowel injury and systemic inflammatory cytokine levels, which results in dramatically improved survival. Unexpectedly, IL-11 also polarizes $\mathrm{T}$ cell responses toward type 2 cytokine secretion (e.g., increased IL-4) and suppresses host macrophage secretion of IL-12. These findings demonstrate that IL-11 modulates the cytokine cascade of GVHD at several steps and suggests that it may have important uses in bone marrow and solid organ transplantation.

\section{Methods}

Mice. Female C57BL/6 (B6, H-2 $2^{\mathrm{b}}$ Ly-5.2 ${ }^{+}$) and B6D2F1 (H-2 ${ }^{\mathrm{b} / \mathrm{d}}$, Ly$\left.5.2^{+}\right)(15)$ mice were purchased from the Jackson Laboratories (Bar Harbor, ME). B6 Ly-5 $5^{\mathrm{a}}\left(\mathrm{H}-2^{\mathrm{b}}, \mathrm{Ly}-5.1^{+}\right)(15)$ mice were purchased from Frederick Cancer Research Facility (Frederick, MD). The age of mice used as bone marrow transplantation (BMT) recipients ranged between 11 and $15 \mathrm{wk}$. Mice were housed in sterilized microisolator cages and received filtered water and normal chow, or autoclaved hyper-chlorinated drinking water for the first two weeks after BMT.

Bone marrow transplantation. Mice were transplanted according to a standard protocol as has been described previously (16). Briefly, on day 0 mice received $1,300 \mathrm{cGy}$ or $1,550 \mathrm{cGy}$ total body irradiation $\left({ }^{137} \mathrm{Cs}\right.$ source), split into two doses separated by $3 \mathrm{~h}$ to minimize gastrointestinal toxicity. $5 \times 10^{6}$ bone marrow cells and $0.5 \times 10^{6}$ or $2 \times$ $10^{6}$ nylon wool purified splenic donor $\mathrm{T}$ cells were resuspended in $0.25 \mathrm{ml}$ of Leibovitz's L-15 media, (Gibco BRL, Gaithersburg, MD)

1. Abbreviations used in this paper: APC, antigen-presenting cell; BMT, bone marrow transplantation; CTL, cytotoxic T lymphocyte; GVHD, graft-versus-host disease; GVL, graft-versus-leukemia; MLC, mixed lymphocyte culture; TBI, total body irradiation; Tc, T cytotoxic; Th, T helper. 
and injected intravenously into recipients after $1,300 \mathrm{cGy}$ or 1,550 cGy of total body irradiation (TBI), respectively. Studies of T cell function and IL-12 production (see Figs. 2 and 4) were performed after 1,300 cGy of TBI to ensure sufficient numbers of living control mice. In some experiments, $\mathrm{Ly}-5^{\mathrm{a}}\left(\mathrm{H}-2^{\mathrm{b}}, \mathrm{Ly}-5.1^{+}\right)$animals were used as donors (see below). Survival was monitored daily, recipient's body weights and GVHD clinical score were measured weekly. Donor cell engraftment was determined by examining percentage of Ly-5.1 ${ }^{+}$ cells in peripheral blood at day 28 after transplantation.

IL-11 treatment. Recombinant human IL-11 was supplied by Genetics Institute (Cambridge, MA) and had a specific activity of 1.6$2.1 \times 10^{6} \mathrm{U} / \mathrm{mg}$ as determined by T10 proliferation assay (17). IL-11 was diluted in $0.1 \%$ BSA/PBS before injection. Mice were injected subcutaneously with IL-11 $(250 \mu \mathrm{g} / \mathrm{kg}$ per dose) twice daily from day -2 to +14 after BMT. Mice from the control groups received injection of diluent only. In some experiments mice received IL-11 only until day +7 after BMT.

Assessment of GVHD. The degree of systemic GVHD was assessed by a scoring system which sums changes in five clinical parameters: weight loss, posture (hunching), activity, fur texture, and skin integrity (maximum index $=10$ ) (18). Individual mice were ear tagged and graded weekly from 0 to 2 for each criterion without knowledge of treatment group.

FACS analysis. FITC-conjugated $\mathrm{mAb}$ to mouse Ly 5.1 and Ly 5.2 antigens, FITC-conjugated $\mathrm{CD} 4$ and phycoerythrin (PE)-conjugated CD8 and B220 were purchased from PharMingen (San Diego, CA). F4/80 antibody, specific for murine macrophages was purchased from Caltag Laboratories (San Francisco, CA). Cells were first incubated with mAb $2.4 \mathrm{G} 2$ for $15 \mathrm{~min}$ at $4^{\circ} \mathrm{C}$, then with the relevant FITC or $\mathrm{PE}$ conjugated $\mathrm{mAb}$ for $30 \mathrm{~min}$ at $4^{\circ} \mathrm{C}$. Finally, cells were washed twice with $\mathrm{PBS} / 0.2 \%$ BSA, fixed with $\mathrm{PBS} / 1 \%$ paraformaldehyde and analyzed by FACScan ${ }^{\circledR}$ (Becton Dickinson, San Jose, CA).

Cell cultures. All culture media, incubation conditions, and studies of TNF $\alpha$ secretion were as previously described (19). Splenocytes were removed from animals $14 \mathrm{~d}$ after transplant and three to six spleens combined from each group. These cells were then layered over Ficoll-paque (Pharmacia LKB Biotechnology, Piscataway, NJ) and centrifuged at $800 \mathrm{~g}$ for $15 \mathrm{~min}$. Cells were then collected from the interface and washed twice before suspension in supplemented $10 \% \mathrm{FCS} / \mathrm{RPMI}-1640$. The percentage of $\mathrm{CD}^{+}$and $\mathrm{CD} 8^{+}$cells in the spleen of the IL-11 and control-treated populations were within $10 \%$ of each other without appreciable differences in CD4:CD8 ratios. These cells were plated in 96-flat bottomed plates (Falcon Labware, Lincoln Park, NJ) at a concentration of $2 \times 10^{5} \mathrm{~T}$ cells $\left(\mathrm{CD}^{+}\right.$plus $\left.\mathrm{CD} 8^{+}\right)$/well with $10^{5}$ irradiated $(2,000 \mathrm{Rad})$ peritoneal macrophages lavaged from naive B6D2F1 (allogeneic) or B6 (syngeneic) animals. At $40 \mathrm{~h}$, cultures were pulsed with ${ }^{3}[\mathrm{H}]$ thymidine $(1 \mu \mathrm{Ci}$ per well $)$ and proliferation was determined $20 \mathrm{~h}$ later on a 1205 Betaplate reader (Wallac, Turku, Finland). In separation experiments, CD4 ${ }^{+}$cells were positively selected from splenocyte populations using the miniMACS system (Miltenyi Biotech, Bergisch Gladbach, Germany). After selection, positive and negative fractions were FACS stained and each fraction had $<1 \%$ contamination of opposing $\mathrm{CD}^{+}$or $\mathrm{CD} 8^{+}$ cells. $\mathrm{CD}^{+}$or $\mathrm{CD}^{+}$populations were then plated with allogeneic macrophages and analyzed as above. T cell number was similarly determined in splenocytes from animals after syngeneic BMT and splenocytes containing $5 \times 10^{4} \mathrm{~T}$ cells were stimulated with $2.5 \mu \mathrm{g} / \mathrm{ml}$ of Con $\mathrm{A}$ and analyzed as above.

Cytokine ELISAs. The antibodies used in the TNF $\alpha$ assays were purchased from Genzyme Corp. (Cambridge, MA). Antibodies used in the IFN $\gamma$, IL-2, IL-4, and IL-12 p40 assays were purchased from PharMingen (San Diego, CA). All assays were performed according to the manufacturer's protocol. Briefly, samples were diluted 1:3 to 1:24 and TNF $\alpha$, IFN $\gamma$, IL-2, IL-4, and IL-12 p40 proteins were captured by the specific primary $\mathrm{mAb}$, and detected by horseradish peroxidase $(\mathrm{TNF} \alpha)$ or biotin-labeled (IFN $\gamma$, IL-2, IL-4, and IL-12 p40) secondary $\mathrm{mAbs}$. The biotin-labeled assays were developed with strepavidin and substrate (Kirkegaard \& Perry Laboratories, Gaithersburg, MD).
Plates were read at $450 \mathrm{~nm}$ using a microplate reader (Bio-Rad Labs, Hercules, CA). Recombinant murine TNF $\alpha$ (Genzyme Corp.) and IFN $\gamma$, IL-2, IL-4, and IL-12 p40 (PharMingen) were used as standards for ELISA assays. Samples and standards were run in duplicate and the sensitivity of the assays was $16-20 \mathrm{pg} / \mathrm{ml}$ for TNF $\alpha$ and IL-12 p40, $0.063 \mathrm{U} / \mathrm{ml}$ for IFN $\gamma$, and $<0.13 \mathrm{U} / \mathrm{ml}$ for IL-2 and IL-4. Supernatants were collected after $4 \mathrm{~h}$ of culture for TNF $\alpha, 24 \mathrm{~h}$ for IL-2, and $48 \mathrm{~h}$ for IFN $\gamma$, IL-12 p40 and IL-4 analysis. For TNF $\alpha$ and IL-12 p40 production by macrophages, results were expressed as units per $10^{5}$ F4/80 positive cells (units/fraction of $\mathrm{F} 4 / 80+$ peritoneal cells).

${ }^{51}$ Cr release assays. $2 \times 10^{6} \mathrm{P} 815\left(\mathrm{H}-2^{\mathrm{d}}\right)$ or EL4 $\left(\mathrm{H}-2^{\mathrm{b}}\right)$ tumor targets were labeled with $100 \mu \mathrm{Ci}$ of ${ }^{51} \mathrm{Cr}$ for $2 \mathrm{~h}$. After washing three times, labeled targets were plated at $10^{4}$ cells per well in $\mathrm{U}$ bottom plates (Costar, Cambridge, MA). Splenocytes from allogeneic BMT recipients (prepared as described above) were added to quadruplicate wells at varying effector to target ratios and incubated for $5 \mathrm{~h}$. Maximal and background release was determined by the addition of Triton-X (Sigma Chemical Co., St Louis, MO) or media alone to targets, respectively. ${ }^{51} \mathrm{Cr}$ activity in supernatants taken $5 \mathrm{~h}$ later were determined in an auto-gamma counter (Cobra, Meriden, CT) and lysis was expressed as a percentage of maximum.

Serum LPS estimation. For determination of endotoxin concentration in serum, the Limulus Amebocyte Lysate (LAL) assay (Bio Whittaker, Walkersville, MD) was performed according to the manufacturer's protocol. Briefly, serum samples were collected and analyzed using pyrogen free materials, diluted 10 -fold (vol/vol) in $\mathrm{LAL}$ reagent water and heated to $70^{\circ} \mathrm{C}$ for $5 \mathrm{~min}$ to remove any nonspecific inhibition to the assay. Samples were then incubated with equal volumes of LAL for $10 \mathrm{~min}$ at $37^{\circ} \mathrm{C}$ and developed with equal volumes of substrate solution for $6 \mathrm{~min}$. The absorbance of the assay plate was read at $405 \mathrm{~nm}$ using the same microplate reader used in cytokine assays. Samples and standards were run in duplicate and the lower limit of detection was $0.15 \mathrm{U} / \mathrm{ml}$. All units expressed are relative to the U.S. reference standard EC-6.

Histology. Formalin-preserved liver, distal small and transverse large bowel were embedded in paraffin, and 5- $\mu \mathrm{m}$ thick sections were stained with haematoxylin and eosin for histologic examination. Slides were coded and examined in a blinded fashion by one individual (J.M. Crawford), using a semi-quantitative scoring system for abnormalities known to be associated with $\operatorname{GVHD}(19,20)$. Specifically, seven parameters each were scored for small bowel (villous blunting, crypt regeneration, crypt epithelial cell apoptosis, crypt loss, luminal sloughing of cellular debris, lamina propria inflammatory cell infiltrate, and mucosal ulceration), large bowel (crypt regeneration, crypt epithelial cell apoptosis, crypt loss, surface colonocyte vacuolization, surface colonocyte attenuation, lamina propria inflammatory cell infiltrate, and mucosal ulceration), and 10 parameters for liver (portal tract expansion by an inflammatory cell infiltrate, lymphocytic infiltrate of bile ducts, bile duct epithelial cell apoptosis, bile duct epithelial cell sloughing, vascular endothelialitis, parenchymal apoptosis, parenchymal microabscesses, parenchymal mitotic figures, hepatocellular cholestasis, and hepatocellular steatosis). The scoring system for each parameter denoted 0 as normal; 0.5 as focal and rare; 1 as focal and mild; 2 as diffuse and mild; 3 as diffuse and moderate; and 4 as diffuse and severe, as previously published in human $(21,22)$ and experimental $(19,20)$ GVHD histology. Scores were added to provide a total score for each organ; the maximum score for small and large bowel was thus 28 each, and for liver 40 .

Electron microscopy. Small intestinal tissue was obtained at necropsy and fixed in Modified McDowell-Trumps fixative and then processed for electron microscopy. Briefly, the specimens were postfixed with $1 \%$ osmium tetroxide and then embedded in Polybd 812 resin (Polysciences Inc). Thin sections were cut and stained with lead citrate and uranyl acetate before study with a Phillips transmission electron microscope operating at $60 \mathrm{kV}$. Multiple sections and grids were examined without knowledge of treatment group.

Statistical analysis. Survival curves were plotted using KaplanMeier estimates. The Mann-Whitney U test was used for the statisti- 
cal analysis of cytokine data, LPS levels, clinical scores, weight loss, and histology while the Mantel-Cox log rank-test was used to analyze survival data. $P<0.05$ was considered statistically significant.

\section{Results}

IL-11 treatment reduces GVHD mortality and morbidity. We first studied the effect of IL-11 administration on GVHD morbidity and mortality following allogeneic BMT using a high TBI dose (1,550 cGy). IL-11 was given from day -2 to day +14 at a dose of $250 \mu \mathrm{g} / \mathrm{kg}$ subcutaneously twice daily. GVHD was severe, with mortality beginning on day +4 and continuing so that $<20 \%$ of control animals treated with diluent alone survived at day 45 (Fig. 1 A). By contrast, 90\% of IL-11treated allogeneic animals survived this period. Survival in syngeneic BMT recipients treated with diluent was $88 \%$ at day 45 (Fig. $1 A$ ). After syngeneic BMT in 9-11-wk-old mice, IL-11 increased long term survival from 60 to $100 \%(P<0.02)$, consistent with its demonstrated protection of the GI tract after
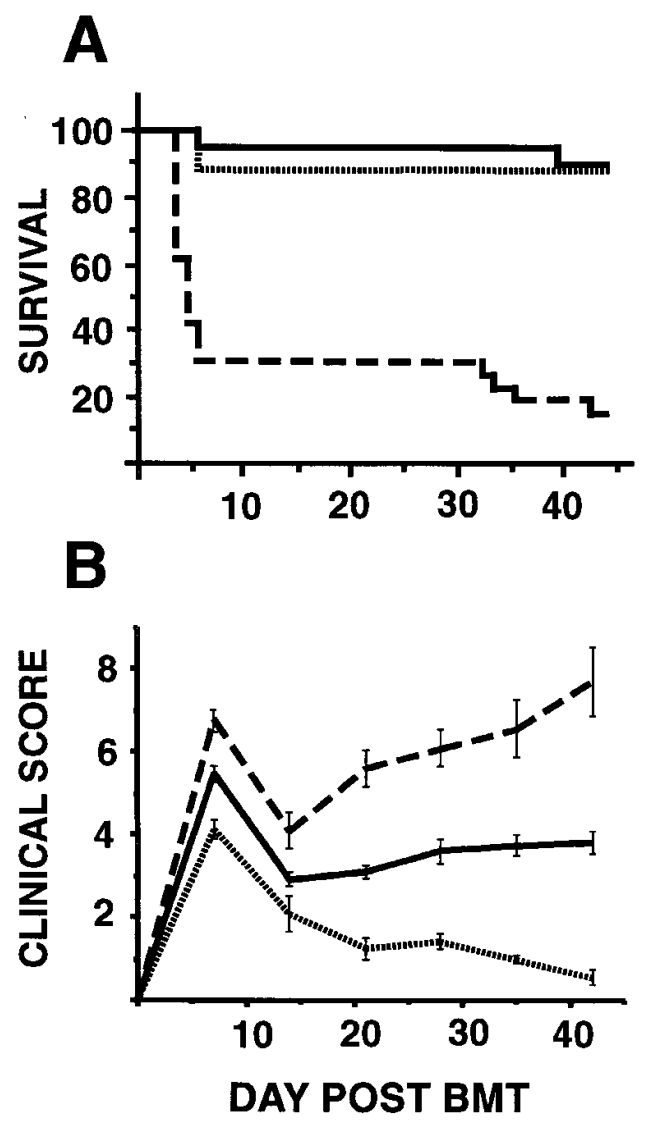

Figure 1. IL-11 reduces the mortality and morbidity of GVHD. B6D2F1 mice were transplanted with $5 \times 10^{6}$ bone marrow cells and $0.5 \times 10^{6} \mathrm{~T}$ cells from B6 mice after 1,550 cGy of TBI. IL-11 or control diluent was given subcutaneously from day -2 to +7 . (A) Survival in control treated (dashed line, $n=20$ ) and IL-11 treated (solid line, $n=20)$ animals after allogeneic BMT $(P<0.001)$ and syngeneic BMT (serrated line, $n=9)$ ). (B) GVHD clinical score. Animals were scored for clinical GVHD as described in Methods. GVHD is significantly less in IL-11-treated animals compared to controls at all time points $(P<0.05)$ and significantly higher than in syngeneic BMT recipients at all time points $(P<0.01)$. Data represent results mean \pm SE from two similar experiments.
TBI $(23,24)$. Clinical GVHD was also quantified using a clinical scoring system as described in Methods $(18,19)$. As shown in Fig. $1 B$, control animals developed severe GVHD (clinical scores $>5$ ) which progressed over the observation period whereas animals treated with IL-11 had only moderate GVHD (clinical scores between 3 and 5) that remained stable over the $45 \mathrm{~d}$. As expected, the clinical scores of syngeneic animals gradually returned to baseline over this time. In separate experiments, IL-11 treatment after a BMT regimen using a lower dose TBI (1,300 cGy) and higher T cell dose $\left(2 \times 10^{6}\right)$ reduced GVHD mortality from 75 to $35 \%$ at day $70(P<0.01)$; the severity of clinical GVHD was also significantly reduced throughout the entire posttransplant period (data not shown). Donor engraftment as determined by Ly 5 phenotype at day 28 (see Methods) was $99.7 \pm 0.2 \%$ in the peripheral blood of IL-11-treated animals compared to $98.1 \pm 1.9 \%$ in controltreated animals, excluding mixed donor/host chimerism as a cause of tolerance to host tissues and reduced GVHD.

IL-11 promotes a Th2/Tc2 cytokine phenotype after BMT but preserves CTL activity. Induction of GVHD fundamentally depends on the donor $\mathrm{T}$ cell response to host alloantigens (25). To evaluate the effects of IL-11 on donor T cell responses to host tissues, we studied $\mathrm{T}$ cell proliferation, cytokine production and CTL activity $14 \mathrm{~d}$ after allogeneic BMT. IL-11 treatment reduced proliferation, IFN $\gamma$, and IL-2 production to host alloantigens by $>50 \%$ in mixed lymphocyte culture (MLC) (Fig. $2 \mathrm{~A}$ ). The stimulation index was reduced from 11.5 in control animals to 2.9 in IL-11-treated animals. IL-4 production by splenocytes from IL-11-treated animals was increased 10 -fold. Over $85 \%$ of this IL-4 $(7.2 \mathrm{U} / \mathrm{ml})$ was derived from $\mathrm{CD}^{+}$compared to $\mathrm{CD}^{+}$cells $(0.95 \mathrm{U} / \mathrm{ml})$. Control $\mathrm{CD}^{+} \mathrm{T}$ cells produced $<0.13 \mathrm{U} / \mathrm{ml}$ of IL- 4 , and thus IL-11 polarized both $\mathrm{T}$ cell subsets (Th2 and Tc2). Splenocytes from IL-11 treated recipients after syngeneic BMT also showed increased IL-4 and decreases in IL-2, IL-12, and IFNy after stimulation with Con A, demonstrating that this effect of IL-11 was not limited to the responses of T cells to alloantigens (Table I). In contrast to the MLC findings, cytotoxic T lymphocyte (CTL) activity to host antigens was similar in control and IL-11treated recipients (Fig. $2 \mathrm{~B}$ ).

To study the physiologic correlates of this $\mathrm{T}$ cell polarization, we analyzed serum IFN $\gamma$ levels $4 \mathrm{~d}$ after allogeneic BMT, when levels are maximal during $\operatorname{GVHD}(26,27)$. Confirming the in vitro findings above, IL-11 treatment significantly reduced serum IFNy levels (Fig. $3 A$ ), which was also seen after allogeneic BMT using 1,300 cGy TBI $(22.3 \pm 2.3$ vs $13.1 \pm 2.5$

Table I. IL-11 Effects on Syngeneic T Cell Responses

\begin{tabular}{lcc}
\hline \multicolumn{1}{c}{ IL-11 treatment } & - & + \\
\hline Proliferation & $49399 \pm 1683$ & $43883 \pm 1543$ \\
IL-12 $(\mathrm{pg} / \mathrm{ml})$ & $255 \pm 19$ & $115^{*} \pm 19$ \\
IFN $\gamma(\mathrm{U} / \mathrm{ml})$ & $134.7 \pm 9.6$ & $73.9^{*} \pm 6.9$ \\
IL-2 $(\mathrm{U} / \mathrm{ml})$ & $13.2 \pm 2.6$ & $5.4^{*} \pm 0.3$ \\
IL-4 $(\mathrm{U} / \mathrm{ml})$ & $10.7 \pm 0.8$ & $21.7^{*} \pm 1.7$ \\
& & \\
\hline
\end{tabular}

Responders were taken at day +14 from syngeneic BMT recipients treated with control diluent or IL-11 and stimulated with Con A. Results represent mean $\pm \mathrm{SD}$ of quadruplicate wells. $\mathrm{T}$ cell cytokine production in the absence of Con A was $<1 \mathrm{U} / \mathrm{ml} . * P<0.05$. 
A

CPM

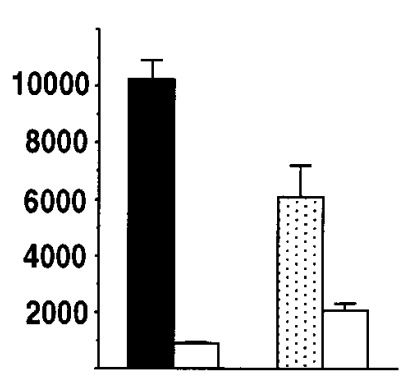

IL-2

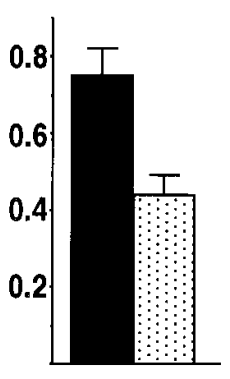

IFN $\gamma$

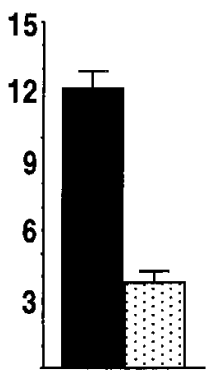

IL-4

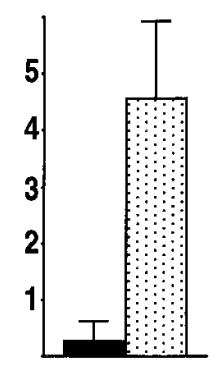

CTL

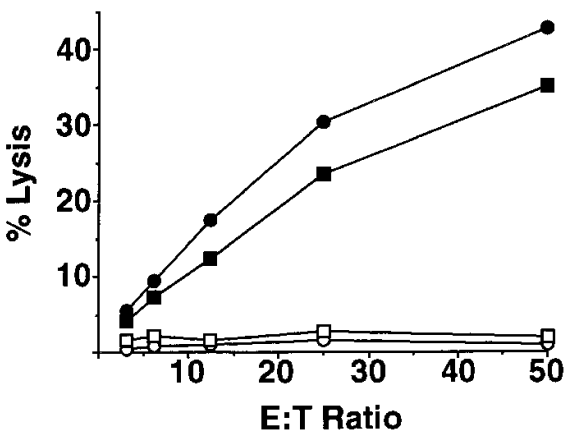

Figure 2. IL-11 administration reduces proliferation and cytokine production of donor cells to host allo-antigens in vitro but does not affect CTL activity. (A) Splenocytes were pooled from IL-11 or control-treated allogeneic animals $(n=3-6) 14 \mathrm{~d}$ after BMT and cultured together with irradiated host macrophages. (Solid bar) Splenocytes from control-treated animals. (Dotted bar) Splenocytes from IL-11-treated animals. (Open bar) Splenocyte responses to donor (B6) peritoneal macrophages. Proliferation was determined by ${ }^{3}[\mathrm{H}]$ thymidine incorporation. The Stimulation Index (expressed as the ratio of proliferation to host stimulators/proliferation to syngeneic stimulators) was 11.5 in controls and 2.9 in IL-11-treated animals. Proliferation of naive B6 splenic T cells to B6D2F1 stimulators was $25,000 \mathrm{cpm}$. Production of IL-2, IFN $\gamma$, and IL-4 by T cells from BMT recipients in response to host stimulators in culture supernatants was determined by ELISA. Solid bar vs dotted bar $P<0.05$. Data represent mean \pm SD of quadruplicate wells and results shown are from one of three similar experiments in which the range of reductions were as follows: proliferation, $60-75 \%$; IFN $\gamma, 40-80 \%$; IL-2, 40-60\%. Increases in IL-4 ranged from eight- to 20-fold. (B) Splenocytes were pooled and used immediately in a standard $5-\mathrm{h}^{51} \mathrm{Cr}$ release assay. Targets were p815 $\left(\mathrm{H}-2^{\mathrm{d}}\right)$ or EL4 (H-2 $)$ tumor cell lines. (๑) Splenocytes from controls against p815. ( $\bigcirc)$ Splenocytes from controls against EL4. (ם) Splenocytes from IL-11-treated animals against p815. ( $\square$ ) Splenocytes from IL-11-treated animals against EL4. Results were similar in three separate experiments in which the percentage of IL-11/control at maximum lysis ranged from 80 to $120 \%$.

$\mathrm{U} / \mathrm{ml}, P<0.05)$. Considered together, these data demonstrate that IL-11 induces a partial Th2/Tc2 cytokine response without affecting cytotoxic $\mathrm{T}$ lymphocyte function.

IL-11 treatment reduces the production of IL-12 during acute GVHD. IL-12 is known to be a critical cytokine in the induction of Th1 responses (11) and blockade of IL-12 during BMT is sufficient to induce a Type 2 cytokine profile and reduce GVHD (28). We hypothesized that IL-11 might polarize $\mathrm{T}$ cell cytokine responses by the down-regulation of IL-12 from antigen presenting cells (APCs). We therefore studied the effect of IL-11 treatment on the production of IL-12 p40 in response to LPS from macrophages $7 \mathrm{~d}$ after BMT. As shown in Fig. $4 A$, the maximum IL-12 p40 production was reduced by over $60 \%$ in IL-11-treated animals. IL-12 production in MLC $14 \mathrm{~d}$ after BMT was also reduced by $60 \%$ (Fig. $4 \mathrm{~B}$ ), which may account for the polarization of donor $\mathrm{T}$ cell responses.

IL-11 treatment reduces small bowel damage and serum LPS levels. Serum LPS levels are increased during GVHD and they correlate with damage to the GI tract (an important target organ of GVHD) (19). IL-11 reduces the damage of chemoradiotherapy to small bowel crypts $(23,24,29)$. We therefore measured serum LPS levels and evaluated small bowel pathology in transplanted animals using a semiquantitative index in which a number of histological parameters were each scored on a scale of 0 to 4 and then summed (see Methods). As shown in Fig. $3 B$, the serum level of LPS at day 5 in animals receiving IL-11 after allogeneic BMT was reduced to that seen after syngeneic BMT. IL-11 treatment also reduced the GI damage in allogeneic BMT recipients to that seen after syngeneic BMT (Fig. 3 C); apoptosis, lymphocytic infiltrate, brush border loss, and sloughing into the lumen were all reduced. Electron microscopy of the small bowel (Fig. 5) revealed that IL-11 dramatically protected the small bowel from severe disruptions in villous integrity characterized by destruction of microvilli, disruption of intercellular tight junctions, and cellular necrosis, helping to explain the profound effects of IL-11 on GVHD mortality.

IL-11 treatment reduces TNF $\alpha$ production in vivo and in vitro. $\mathrm{TNF} \alpha$ is an inflammatory cytokine that acts in several phases of GVHD pathophysiology $(11,13,19,30)$. Because TBI alone can potentiate TNF $\alpha$ production by macrophages in response to LPS (19), we evaluated macrophages taken from animals immediately after TBI. IL-11 pretreatment for $2 \mathrm{~d}$ significantly suppressed TNF $\alpha$ secretion to LPS after TBI ( $464 \pm 36$ vs $223 \pm 12 \mathrm{pg}, P<0.05$ ), reducing it to that secreted by unirradiated macrophages $(197 \pm 16 \mathrm{pg})$. Similar reductions were also seen in the presence of IFN $\gamma$ priming (data not shown), confirming the potency of IL-11 in abrogating the proinflammatory effects of TBI. Polarization of T cells before BMT also reduces TNF $\alpha$ levels and prevents mortality (31). Given the findings above, we hypothesized that IL-11 could also decrease TNF $\alpha$ during acute GVHD both because T cells were polarized and less able to prime mononuclear cells, and because LPS was contained within an intact GI tract and was unable to translocate to the systemic circulation. Serum TNF $\alpha$ levels were therefore measured in BMT recipients at day +5 , the time of peak mortality. As shown in Fig. $3 \mathrm{D}$, IL-11 treat- 


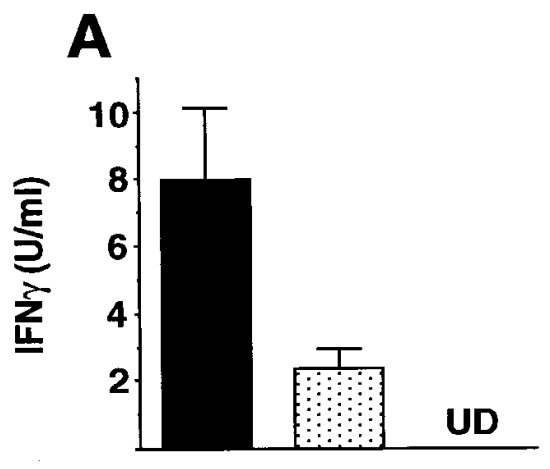

B
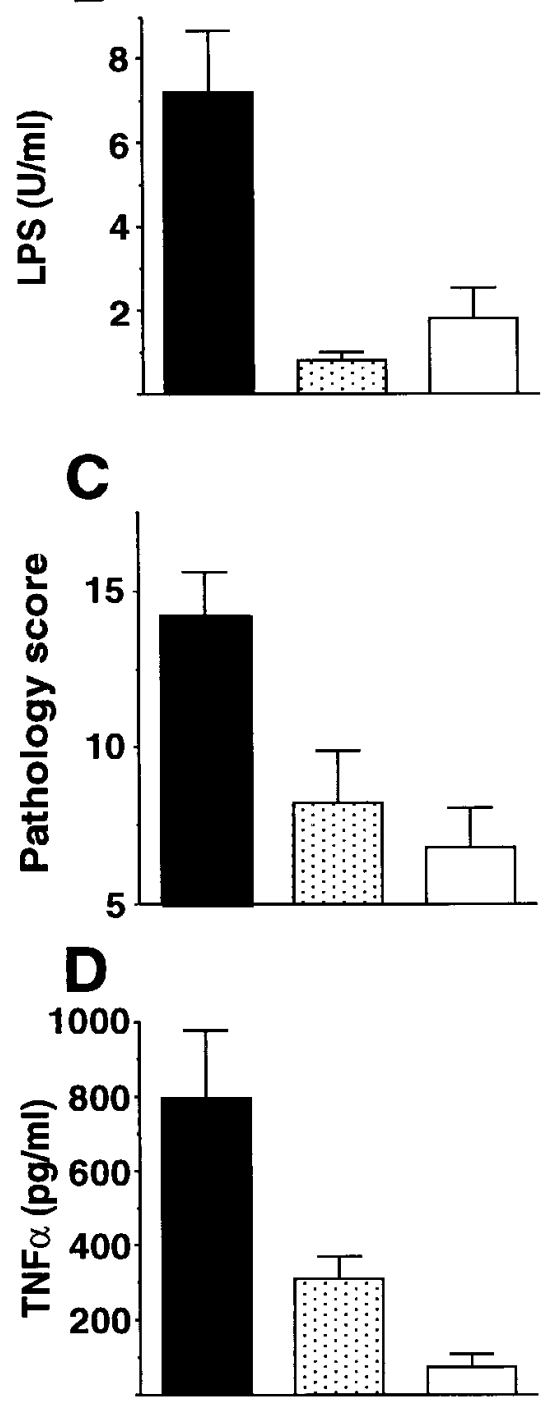

Figure 3. (A) IL-11 reduces early systemic IFN $\gamma$ levels after allogeneic BMT. IFN $\gamma$ levels were determined in sera from animals $4 \mathrm{~d}$ after allogeneic BMT. (Solid bar) Controls, $(n=10)$; (dotted bar) IL11-treated animals $(n=10)$. Levels after syngeneic BMT were under the limit of detection (UD), $(n=4)$. Dotted bar vs solid bar and dotted bar vs UD, $P<0.01$. (B) IL-11 reduces systemic LPS serum levels $5 \mathrm{~d}$ after allogeneic BMT. (Solid bar) Controls $(n=14)$. (Dotted bar) IL-11-treated animals $(n=12)$. (Open bar) Syngeneic BMT recipients, $(n=10)$. Solid bar vs dotted bar and solid bar vs open bar, $P<0.01$. (C) IL-11 reduces small bowel damage after allogeneic BMT. Randomized coded slides were scored semi-quantitatively, as ment significantly reduced serum $\mathrm{TNF} \alpha$ levels in allogeneic $\mathrm{BMT}$ recipients, albeit to levels that remained higher than after syngeneic BMT.

Brief IL-11 treatment provides long-term protection of GVHD target organs. Previous studies have shown that Th2 polarization alone does not always prevent GVHD target tissue damage despite improved survival (32). We therefore studied the long-term effects of IL-11 on two GVHD target organs, the GI tract and liver (33). Samples were taken from animals $45 \mathrm{~d}$ after transplantation and processed and scored as described in Methods. Table II shows that IL-11 treatment protected the small bowel to the greatest extent, although there is also a trend towards less damage in the large bowel and liver. Combined histopathologic scores for small bowel, large bowel, and liver demonstrated a significant overall protection. In addition, the profound immunosuppression of GVHD, reflected in delayed $\mathrm{T}$ and $\mathrm{B}$ cell reconstitution $(34,35)$, was significantly reduced by IL-11 (Table II).

\section{Discussion}

We have shown that IL-11 substantially reduces GVHD morbidity and mortality in an experimental BMT model. Shortterm administration of IL-11 not only improved recipient survival, but provided long-term protection of GVHD target organs, especially the small intestine. Our data demonstrate that IL-11 achieves this effect at three points within the cytokine cascade of acute GVHD (Fig. 6). First, during recipient conditioning, IL-11 minimizes GVHD damage to the small bowel and prevents the sensitization of host macrophages to the effects of TBI which reduces LPS levels. During phase 2 (donor T cell activation), IL-11 induces polarization of donor $\mathrm{T}$ cells by downregulating IL-12, subsequently reducing the production of IFN $\gamma$ both in vivo and in vitro. Finally, IL-11 directly suppresses the production of inflammatory cytokines by monocytes and macrophages in response to LPS during phase 3 , thereby further suppressing the secretion of TNF $\alpha$ that contributes to target cell apoptosis.

The ability of IL-11 to reduce small bowel injury (Fig. $3 C$ ) is critical to its prevention of systemic GVHD. At least two potential mechanisms may be involved. First, IL-11 has direct protective effects on the GI tract epithelium in models of chemotherapy and radiation induced injury $(23,24,29,36,37)$. Small bowel crypt recovery is improved via protection of clonogenic crypt cells (24), reductions in apoptosis (29), and increased cellular mitotic index after chemoradiotherapy (23). These studies, which served as the basis for the IL-11 treatment schedule used in our experiments, showed that maximum crypt protection occurred if IL-11 treatment began before irradiation and then continued for a further $3 \mathrm{~d}$ (24). The ability of IL-11 to enhance the structural integrity of the gastrointestinal

described in Methods. The total scores are shown for specimens from each animal group. (Solid bar) Controls, $(n=20)$ (dotted bar) IL-11treated animals $(n=10)$; and (open bar) syngeneic BMT recipients $(n=9)$. Solid bar vs dotted bar and solid bar vs open bar, $P<0.01$. $(D)$ IL-11 reduces TNF $\alpha$ production in vivo. TNF $\alpha$ levels were determined in the sera of animals $5 \mathrm{~d}$ after BMT. (Solid bar) Controls $(n=$ $14)$; (dotted bar) IL-11-treated animals, $(n=10)$ and (open bar) syngeneic BMT recipients $(n=9)$. Solid bar vs dotted bar, $P<0.05$, dotted bar vs open bar, $P<0.01$. All results represent mean \pm SE. 


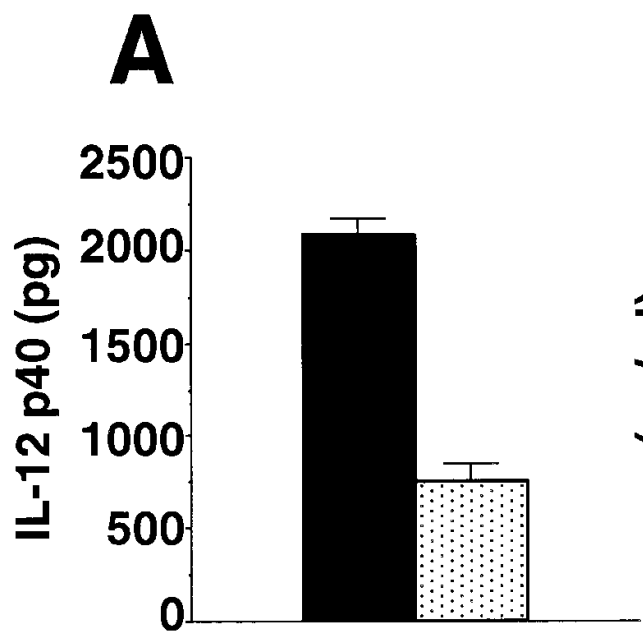

B

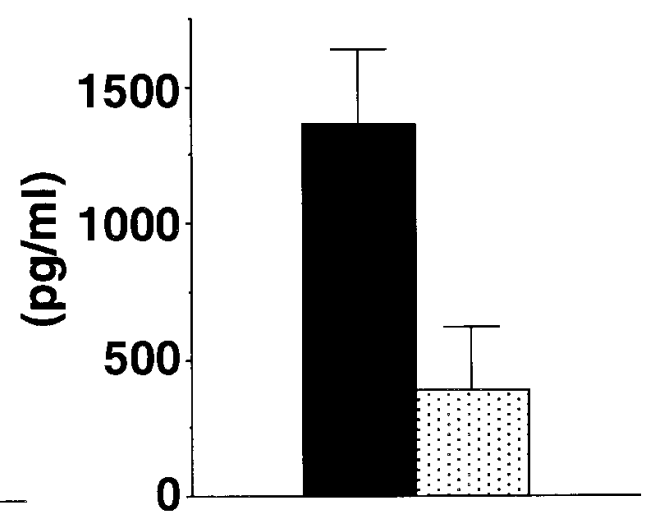

Figure 4. IL-11 reduces IL-12 p40 production. (A) Macrophages were pooled from four allogeneic recipients $7 \mathrm{~d}$ after BMT in each treatment group and cultured in the presence of LPS $(0.01 \mu \mathrm{g} / \mathrm{ml})$. Supernatants were collected at $48 \mathrm{~h}$ and analyzed by ELISA. Data represents mean $\pm \mathrm{SD}$ of quadruplicate wells, expressed as units per $10^{5} \mathrm{~F} 4 /$ $80+$ cells. Macrophages from syngeneic BMT recipients produced $203 \pm 24$ pg. Dotted bar vs solid bar, $P<0.05$. (B) Supernatants taken $48 \mathrm{~h}$ after initiation of MLC as in Fig. 2 were analyzed by ELISA. Data represent combined mean \pm SD of three experiments. Dotted bar vs solid bar, $P<0.01$. mucosal barrier (Fig. 5) has also been noted in experimental models of colitis (38). The requirement that IL-11 treatment be commenced before conditioning may reflect its ability to decrease epithelial proliferation (and hence susceptibility to damage) due to prolongation of the G1-S phase of the cell cycle (39). Furthermore, the trophic effect of IL-11 on already damaged small bowel epithelium $(23,40)$ implies a second mechanism that operates independently of the cell cycle.

A second pathway by which IL-11 may protect the GI tract is by direct suppression of inflammatory cytokines. TNF $\alpha$ causes necrosis in the GI tract (41) and IFN $\gamma$ increases mucosal permeability by altering tight junction integrity $(42,43)$. Individual blockade of each of these cytokines during GVHD reduces GI tract injury $(41,44)$ and additive effects might therefore be expected by IL-11 treatment. The maintenance of tight junction integrity and preservation of the GI epithelium (observed in IL-11-treated recipients) is consistent with reduced levels of both these cytokines. The normal CTL responses to alloantigens in IL-11-treated animals suggest that CTL effectors alone are not responsible for the small bowel injury during GVHD. Although surprising, this conclusion is consistent with the findings of Baker et al. who demonstrated variability among GVHD target organ susceptibility to CTL damage (45). Such variations were confirmed in a recent study where FasL (but not TNF $\alpha$ ) mediated GVHD hepatic damage and TNF $\alpha$, (but not FasL) was an important effector of GI tract damage (46). Both the FasL and TNF $\alpha$ pathway caused GVHD skin pathology. The GI tract seems particularly susceptible to the inflammatory cytokines generated during GVHD and IL-11 may reduce this susceptibility directly by maintaining epithelial cellular structure and indirectly by reducing MHC antigen expression through decreases in IFN $\gamma$. The individual contributions of each of these potential mechanisms is currently under investigation.

The polarization of T cells by IL-11 during T cell activation appears to be mediated by the suppression of IL-12, although IL-11 may have additional direct effects on T cells which are known to bear IL-11 receptors (Trepicchio, W., personal communication). IL-11 has been shown to block IL-12 p70 production from human peripheral blood mononuclear cells in vitro (10). Our data are the first to confirm a physiological conse- quence of this effect, because IL-12 p40 levels correlate closely with biologically active IL-12 p70 (12). The inhibition of IL-12 is important, since blockade of IL-12 results in Th2 polarization (28), the default T cell pathway in the absence of IFNyproducing cells (47). The ability of IL-11 to polarize T cell cytokine production is consistent with the obligatory role of IL-12 in the generation of Th1/Tc1 cells (48) although polarization by IL-4 does not effect CTL generation and the cytolytic capacity of Tc2 cells is not impaired (49). The unaffected CTL response in IL-11-treated animals, which is mediated by mature $\mathrm{CD}^{+} \mathrm{T}$ cells in this model (50), is therefore not surprising. Indeed, preservation of the CTL response may have important implications for maintaining a graft-versus-leukemia (GVL) effect, a therapeutic benefit of allogeneic BMT in malignant diseases. The separation of GVHD and GVL through inhibition of $\mathrm{CD}^{+}$cells has been demonstrated in other experimental BMT models $(51,52)$.

The ability of $\mathrm{Th} 2$ cytokine polarization of donor $\mathrm{T}$ cells to reduce the severity of acute GVHD has been shown in a number of different experimental models, although the methods used to induce polarization have differed in each instance. First, the administration of IL-4 to donor mice induces a Th2 phenotype and when these cells are used in the donor inoculum, GVHD is reduced $(31,53)$. Second, the addition of IL-4 to primary MLC of donor T cells and host stimulator cells results in $\mathrm{T}$ cell polarization and a reduction in acute GVHD when these cells are used as the donor T cell inoculum (16). However, GVHD target organs are not protected long-term by this approach (32). Third, the use of G-CSF for the mobilization of donor cells also induces Th2 polarization and reduces GVHD (54), which may help to explain the lower incidence of severe acute GVHD observed after transplantation using G-CSF mobilized stem cells (55). Indeed, G-CSF mobilized donor cells contain up to 10 -fold more $\mathrm{T}$ cells than in conventional BMT, but their use is not associated with the predicted increase in acute GVHD (56), although chronic GVHD may be increased (57). All these approaches interrupt the cascade that leads to secretion of inflammatory cytokines such as $\mathrm{TNF} \alpha$ through reductions in IFN $\gamma$ priming of monocytes (16, $28,54)$.

The suppression of inflammatory cytokines by IL-11 has 

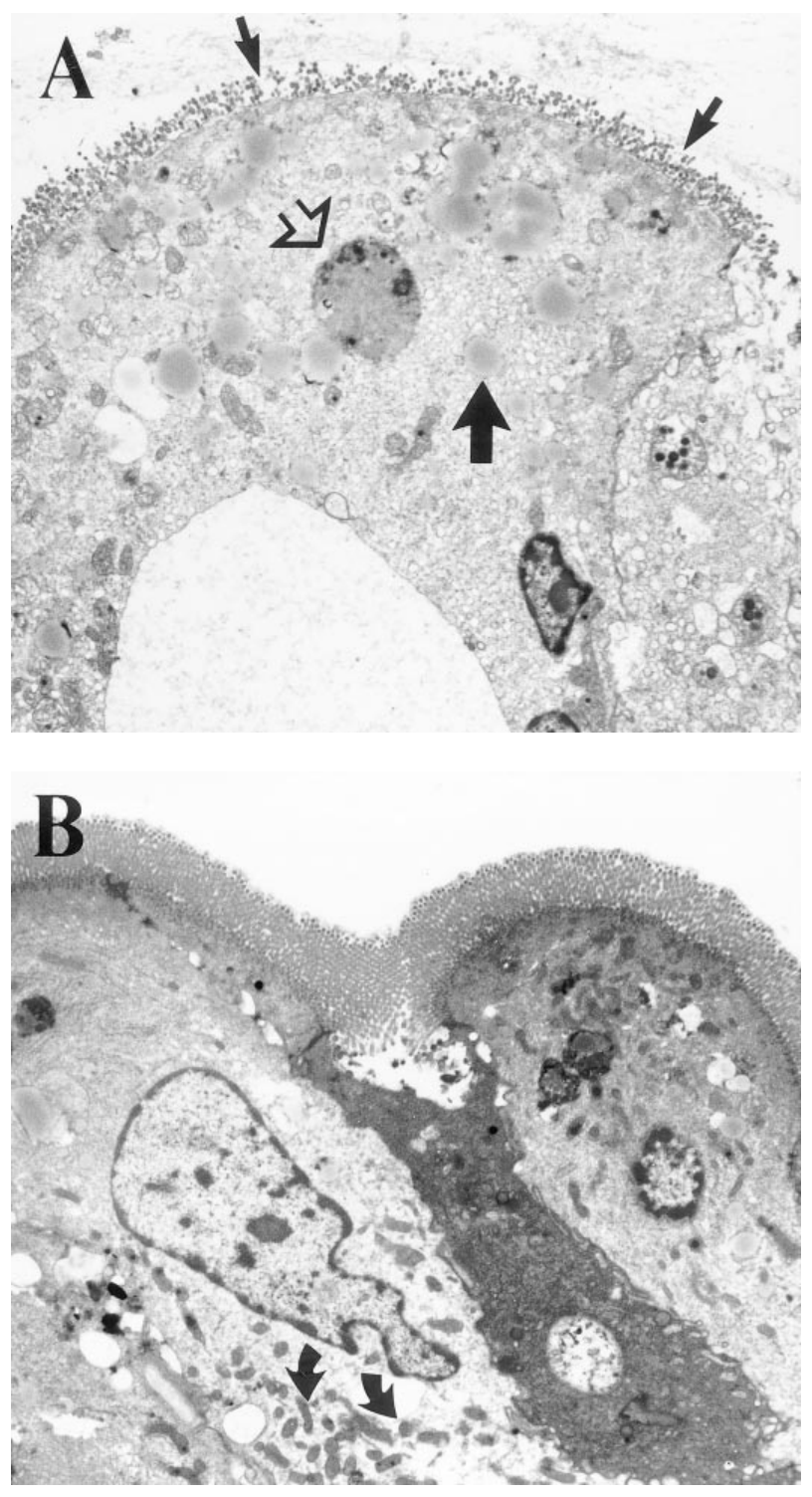

Figure 5. IL-11 preserves the integrity of the small bowel during acute GVHD. Transmission electron microscopy viewed at 3,300× of epithelium of the small intestine $5 \mathrm{~d}$ after allogeneic BMT using 1,550 cGy of TBI as conditioning. (A) diluent and (B) IL-11-treated animals. Note the loss of surface microvilli (thin solid arrows) and the apoptotic apical cell with pyknotic nuclear changes (open arrow), and lipid dissolution (thick solid arrows) $(A)$. Intact intercellular junctions, viable cytoplasmic organelles (mitochondria, curved arrows), and normal microvilli are evident in $(B)$.

recently been the focus of intensive research $(5,7,10)$. In a mouse model of endotoxemia, pretreatment with IL-11 prevented increases in TNF $\alpha$, IL-1 $\beta$, and IFN $\gamma$ production after LPS stimulation in vitro and in vivo (5) and is thought to be the result of NF-кB suppression (6). In preclinical studies, IL-11 has been shown to protect the lung from radiation-induced injury through nearly complete inhibition of $\mathrm{TNF} \alpha$ production (7). The ability of IL-11 to improve inflammatory bowel disease also shows therapeutic promise (8). The mechanism for this improvement has not yet been elucidated, but the correlation with Th1 dominance of inflammatory bowel disease is in-
Table II. Day 45 Target Organ GVHD Pathology and Immune Reconstitution

\begin{tabular}{lccc}
\hline & $\begin{array}{c}\text { ALLO }+ \text { control } \\
(n=4)\end{array}$ & $\begin{array}{c}\text { ALLO }+ \text { IL-11 } \\
(n=5-9)\end{array}$ & $\begin{array}{c}\text { Syngeneic } \\
(n=3)\end{array}$ \\
\hline GI histology score & & & \\
$\quad$ Small bowel & $10.8 \pm 1.5$ & $3.8 \pm 0.8^{*}$ & $6.0 \pm 1.2^{\Downarrow}$ \\
Large bowel & $5.3 \pm 2.3$ & $3.7 \pm 0.4$ & $2.0 \pm 0.0^{\S}$ \\
Liver & $11.3 \pm 2.8$ & $8.7 \pm 1.2$ & $6.0 \pm 1.5^{\S}$ \\
$\quad$ Total GVHD score & $27.0 \pm 3.2$ & $16.1 \pm 1.5^{\ddagger}$ & $13.3 \pm 2.0^{\S}$ \\
Immune reconstitution & & & \\
CD4+ & $0.61 \pm 0.23$ & $2.61 \pm 0.41^{\ddagger}$ & $12.0 \pm 0.51^{\S}$ \\
CD8+ & $0.50 \pm 0.13$ & $1.45 \pm 0.14^{\ddagger}$ & $5.50 \pm 0.46^{\S}$ \\
B220+ & $0.83 \pm 0.56$ & $6.92 \pm 1.40^{\S}$ & $55.89 \pm 10.86^{\S}$ \\
& & & \\
\hline
\end{tabular}

Scores (0-4) for each parameter below were assessed on coded slides and summed as described in Methods. Small bowel: villous blunting, crypt regeneration, loss of enterocyte brush border, luminal sloughing of cellular debris, crypt cell apoptosis, outright crypt destruction, and lamina propria lymphocytic infiltrate. Large bowel: crypt regeneration, surface coloncytes, coloncyte vacuolization, surface colonocyte attenuation, crypt cell apoptosis, outright crypt destruction, and lamina propria lymphocytic infiltrate. Liver: portal tract expansion and infiltrate, bile duct infiltrate, nuclear multilayering, pyknotic duct cells, intraepithelial cells, vascular endothelialitis, hepatocellular pan-lobular necrosis, acidophil bodies, microabscesses, mitotic figures, and steatosis. Total GVHD score: mean $\pm \mathrm{SE}$ of the sum of scores for small bowel, large bowel, and liver from individual animals in each group. Immune reconstitution: mean $\pm \mathrm{SE}$ of $\mathrm{CD}^{+}, \mathrm{CD}^{+}$, and $\mathrm{B} 220^{+}$cells $\left(\times 10^{6}\right.$ per spleen $) .{ }^{*} P<$ 0.01 vs allo + control, ${ }^{\ddagger} P<0.02$ vs allo + control, ${ }^{\S} P<0.05$ vs allo + control, ${ }^{\|} P=0.08$ vs allo + control.

triguing $(58,59)$, particularly as IL-11 tends to polarize T cell function toward Th2 cytokines. Taken together, our data suggest that IL-11 suppresses TNF $\alpha$ generation during GVHD by: (a) a direct suppression of TNF $\alpha$ secretion by monocytes; $(b)$ a reduction in IFN $\gamma$ (which sensitizes macrophages to LPS); (c) reduced systemic LPS levels that could stimulate production of $\mathrm{TNF} \alpha$.

Acute GVHD remains the major obstacle to the wider application of allogeneic BMT. Clinical BMT requires intensive conditioning regimens which increase the severity of GVHD by amplifying the inflammatory cytokine cascade (19). Current immunosuppressive drugs such as cyclosporine $\mathrm{A}$ and prednisone offer significant but incomplete protection against GVHD, particularly in the setting of multiple donor-host histocompatibility antigen disparities that pertain to unrelated donor BMT. Interestingly, cyclosporine A is a poor inhibitor of IFN $\gamma$ secretion induced by IL-12 (60) and IL-11 may therefore offer an attractive noncross-reactive strategy to suppress both the IL-12 driven T cell response and the inflammatory response mediated by LPS. The ability of IL-11 to alter such cytokine profiles may also hold therapeutic potential for other diseases where Th1 responses play a prominent pathogenic role, such as autoimmune diseases (61) and rejection of solid organ transplants where Th2 cytokines appear to reduce the barrier to tolerance despite efficient CTL generation (62).

\section{Acknowledgments}

This work was supported by National Institutes of Health grants CA39542 and HL-55162 (J.L.M. Ferrara). J.L.M. Ferrara is a scholar 


\section{(1) Recipient conditioning}

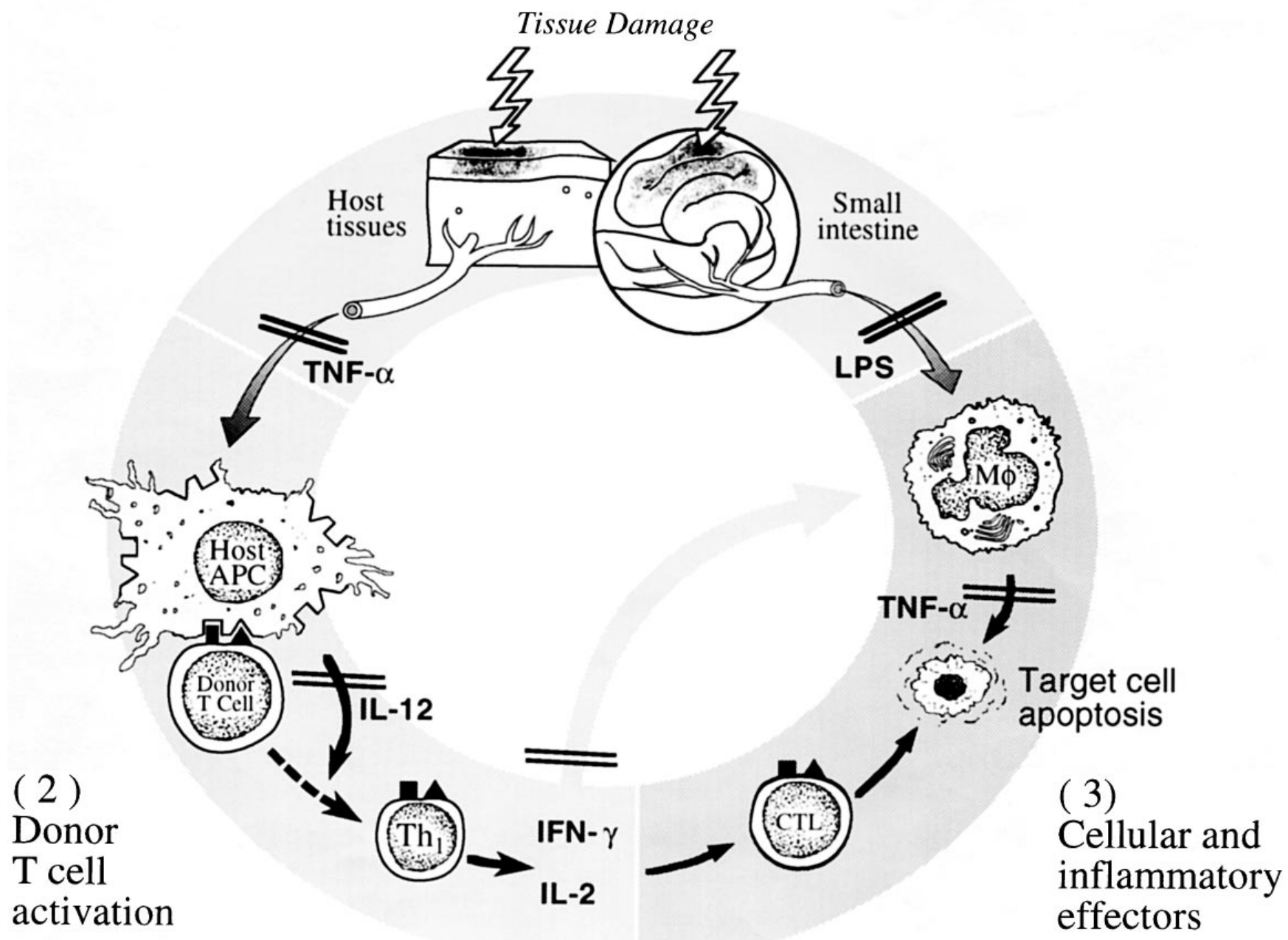

Figure 6. The effects of IL-11 on the cytokine cascades of GVHD. The development of acute GVHD is proposed to develop in a three-phase process where mononuclear phagocytes and other accessory cells are responsible for both initiation of a GVH reaction and for the subsequent injury to host tissues after complex interactions with cytokines. In phase 1, IL-11 reduces damage from the conditioning regimen in the intestinal mucosa, which prevents translocation of LPS from the intestinal lumen into the circulation. IL-11 also reduces the sensitization of host macrophages by TBI to secrete TNF $\alpha$ and it diminishes IL-12 production by host APCs. As a consequence, IL-11 prevents IFN $\gamma$ secretion by donor T cells (although CTL function remains unaffected) and systemic TNF $\alpha$ is lowered, culminating in reduced target organ damage and improved survival.

of the Leukemia Society of America. G.R. Hill is supported by the Children's Surgical Research Foundation.

\section{References}

1. Du, X., and D.A. Williams. 1997. Interleukin IL-11: review of molecular, cell biology, and clinical use. Blood. 11:3897-3908.

2. Du, X., T. Neben, S. Goldman, and D.A. Williams. 1993. Effects of recombinant human interleukin-11 on hematopoietic reconstitution in transplant mice: acceleration of recovery of peripheral blood neutrophils and platelets. Blood. 81:27-34.

3. Teicher, B.A., Y.N. Chen, G. Ara, Y. Emi, Y. Kakeji, Y. Maehara, S. Keyes, and D. Northey. 1996. Interaction of interleukin-11 with cytotoxic therapies in vitro against CEM cells and in vivo against EMT-6 murine mammary carcinoma. Int. J. Cancer. 67:864-870.

4. Maze, R., T. Moritz, and D.A. Williams. 1994. Increased survival and multilineage hematopoietic protection from delayed and severe myelosuppressive effects of a nitrosourea with recombinant interleukin-11. Cancer Res. 54:
4947-4951.

5. Trepicchio, W.L., M. Bozza, G. Pedneault, and A.J. Dorner. 1996. Recombinant human IL-11 attenuates the inflammatory response through down regulation of proinflammatory cytokine release and nitric oxide production. $J$. Immunol. 157:3627-3634.

6. Trepicchio, W.L., L. Wang, M. Bozza, and A.J. Dorner. 1997. Interleukin-11 regulates macrophage effector function through the inhibition of NF-KB. J. Immunol. 159:5661-5671.

7. Redlich, C.A., X. Gao, and S. Rockwell. 1996. IL-11 enhances survival and decreases TNF production after radiation-induced thoracic injury. J. Immunol. 157:1705-1710.

8. Qui, B.S., C.J. Pfieffer, and J.C. Keith. 1996. Protection by recombinant interleukin-11 against experimental TNB-induced colitis. Dig. Dis. Sci. 41: $1625-1630$.

9. Chang, M., A. Williams, L. Ishizawa, A. Knoppel, C. van de Ven, and M.S. Cairo. 1996. Endogenous interleukin-11 expression is increased and prophylactic use of exogenous IL-11 enhances platelet recovery and improves survival during thrombocytopenia associated with experimental group B streptococcal sepsis in neonatal rats. Blood Cells Mol. Dis. 22:57-67.

10. Leng, S.X., and J.A. Elias. 1997. Interleukin-11 inhibits macrophage in- 
terleukin-12 production. J. Immunol. 159:2161-2168.

11. Krenger, W., G.R. Hill, and J.L.M. Ferrara. 1997. Cytokine cascades in acute graft-versus-host disease. Transplantation (Baltimore). 64:553-558.

12. Kichian, K., F.P. Nestel, D. Kim, P. Ponka, and W.S. Lapp. 1996. IL-12 p40 message RNA expression in target organs during acute graft-versus-host disease. Possible involvement of IFN-gamma. J. Immunol. 157:2851-2856.

13. Nestel, F.P., K.S. Price, T.A. Seemayer, and W.S. Lapp. 1992. Macrophage priming and lipopolysaccharide-triggered release of tumor necrosis factor alpha during graft-versus-host disease. J. Exp. Med. 175:405-413.

14. Hill, G.R., W. Krenger, and J.L.M. Ferrara. 1997. The role of cytokines in acute graft-versus-host disease. Cytokines: cellular and molecular therapy. 3 : $257-265$

15. Morse, H.C., F.W. Shen, and U. Hammerling. 1987. Genetic nomenclature for loci controlling mouse lymphocyte antigens. Immunogenetics. 25:71-78.

16. Krenger, W., K.M. Snyder, C.H. Byon, G. Falzarano, and J.L.M. Ferrara. 1995. Polarized type 2 alloreactive CD4+ and CD8+ donor T cells fail to induce experimental acute graft-versus-host disease. J. Immunol. 155:585-593.

17. Paul, S.R., B.A. Barut, F. Bennett, M.A. Cochran, and K.C. Anderson. 1992. Lack of a role of interleukin-11 in the growth of multiple myeloma. Leuk. Res. 16:247-252.

18. Cooke, K.R., L. Kobzik, T.R. Martin, J. Brewer, J. Delmonte, J.M. Crawford, and J.L.M. Ferrara. 1996. An experimental model of idiopathic pneumonia syndrome after bone marrow transplantation. I. The roles of minor $\mathrm{H}$ antigens and endotoxin. Blood. 88:3230-3239.

19. Hill, G.R., J.M. Crawford, K.J. Cooke, Y.S. Brinson, L. Pan, and J.L.M. Ferrara. 1997. Total body irradiation effects on acute graft versus host disease. The role of gastrointestinal damage and inflammatory cytokines. Blood. 90: 3204-3213.

20. Blatter, D.D., J.M. Crawford, and J.L.M. Ferrara. 1990. Nuclear magnetic resonance of hepatic graft-versus-host disease in mice. Transplantation (Baltimore). 50:1011-1018.

21. Snover, D.C., S.A. Weisdorf, G.M. Vercellotti, B. Rank, S. Hutton, and P. McGlave. 1985. A histopathologic study of gastric and small intestinal graftversus-host disease following allogeneic bone marrow transplantation. Hum. Pathol. 16:387-392.

22. Snover, D.C., S.A. Weisdorf, N.K. Ramsay, P. McGlave, and J.H. Kersey. 1984. Hepatic graft-versus-host disease: a study of the predictive value of liver biopsy in diagnosis. Hepatology. 4:123-130.

23. Du, X.X., C.M. Doerschuk, A. Orazi, and D.A. Williams. 1994. A bone marrow stromal-derived growth factor, interleukin-11, stimulates recovery of small intestinal mucosal cells after cytoablative therapy. Blood. 83:33-37.

24. Potten, C.S. 1996. Protection of the small intestinal clonogenic stem cells from radiation-induced damage by pretreatment with interleukin 11 also increases murine survival time. Int. J. Cancer. 14:452-459.

25. Ferrara, J.L.M., and H.J. Deeg. 1991. Graft versus host disease. N. Engl. J. Med. 324:667-674.

26. Szebeni, J., M.G. Wang, D.A. Pearson, G.L. Szot, and M. Sykes. 1994. IL-2 inhibits early increases in serum gamma interferon levels associated with graft-versus-host disease. Transplantation (Baltimore). 58:1385-1393.

27. Sykes, M., G.L. Szot, P.L. Nguyen, and D.A. Pearson. 1995. Interleukin12 inhibits murine graft-versus-host disease. Blood. 86:2429-2438.

28. Williamson, E., P. Garside, J.A. Bradley, I.A.R. More, and A.M. Mowat. 1997. Neutralizing IL-12 during induction of murine acute graft-versushost disease polarizes the cytokine profile toward a Th2-type alloimmune response and confers long term protection from disease. J. Immunol. 159:12081215.

29. Orazi, A., X. Du, Z. Yang, M. Kashai, and D.A. Williams. 1996. Interleukin-11 prevents apoptosis and accelerates recovery of small intestinal mucosa in mice treated with combined chemotherapy and radiation. Lab. Invest. 75:33-42.

30. Antin, J.H., and J.L.M. Ferrara. 1992. Cytokine dysregulation and acute graft-versus-host disease. Blood. 80:2964-2968.

31. Fowler, D.H., K. Kurasawa, R. Smith, and R.E. Gress. 1994. Donor lymphoid cells of Th2 cytokine phenotype reduce lethal graft versus host disease and facilitate fully allogeneic cell transfers in sublethally irradiated mice. Prog. Clin. Biol. Res. 389:533-540.

32. Krenger, W., K.R. Cooke, S.T. Sonis, J. Crawford, R. Simmons, L. Pan, L. Kobzik, J. Delmonte, M. Karandikar, and J.L.M. Ferrara. 1996. Transplantation of polarized type 2 donor T cells reduces mortality caused by experimental graft-versus-host disease. Transplantation (Baltimore). 62:1278-1285.

33. Ringden, O., and H.J. Deeg. 1997. Clinical spectrum of graft-versus-host disease. In Graft-vs-Host Disease, 2nd edition. J.L.M. Ferrara, H.J. Deeg, and S.J. Burakoff, editors. Marcel Dekker, Inc., NY. 525-559.

34. Hakim, F.T., S. Payne, and G.M. Shearer. 1994. Recovery of T cell populations after acute graft-vs-host reaction. J. Immunol. 152:58-64.

35. Storek, J., and A. Saxon. 1992. Reconstitution of B cell immunity following bone marrow transplantation. Bone Marrow Transplant. 9:395-408.

36. Keith, J.C., L. Albert, S.T. Sonis, C.J. Pfeiffer, and R.G. Schaub. 1994. IL-11, a pleotropic cytokine: exciting new effects of IL-11 on gastrointestinal mucosal biology. Stem Cells. 12:79-90.

37. Sonis, S., A. Muska, J. O'Brien, A. Van Vugt, P. Langer-Safer, and J. Keith. 1995. Alteration in the frequency, severity and duration of chemother- apy-induced mucositis in hamsters by IL-11. Eur. J. Cancer. 31B:261-266.

38. Pfieffer, C.J., S. Sato, B.S. Qiu, J.C. Keith, and S. Evangelistia. 1997. Cellular pathology of experimental colitis induced by trinitrobenzenesulfonic acid (TNBS): protective effects of recombinant human interleukin-11. Immunopharmacology. 5:363-381.

39. Peterson, R.L., M.M. Bozza, and A.J. Dorner. 1996. Interleukin-11 induces epithelial cell growth arrest through effects on retinoblastoma protein phosphorylation. Am. J. Pathol. 149:895-902.

40. Liu, Q., X.X. Du, D.T. Schindel, Z.X. Yang, F.J. Rescorla, D.A. Williams, and J.L. Grosfeld. 1996. Trophic effects of IL-11 in rats with experimental short bowel syndrome. J. Pediatr. Surg. 31:1047-1050.

41. Piguet, P.F., G.E. Grau, B. Allet, and P.J. Vassalli. 1987. Tumor necrosis factor/cachectin is an effector of skin and gut lesions of the acute phase of graftversus-host disease. J. Exp. Med. 166:1280-1289.

42. Madara, J.L., and J. Stafford. 1989. Interferon- $\gamma$ directly affects barrier function of cultured intestinal epithelial monolayers. J. Clin. Invest. 83:724-727. 43. Adams, R.B., S.M. Planchon, and J.K. Roche. 1993. IFN- $\gamma$ modulation of epithelial barrier function. J. Immunol. 150:2356-2363.

44. Mowat, A. 1989. Antibodies to IFN-gamma prevent immunological mediated intestinal damage in murine graft-versus-host reactions. Immunology. 68:18-24.

45. Baker, M.B., N.H. Altman, E.R. Podack, and R.B. Levy. 1996. The role of cell-mediated cytotoxicity in acute GVHD after MHC-matched allogeneic bone marrow transplantation in mice. J. Exp. Med. 183:2645-2656.

46. Hattori, K., T. Hirano, M. Tateno, K. Oshimi, N. Kayagaki, H. Yagita, and K. Okumura. 1997. The synergistic effects of anti-Fas ligand and TNF- $\alpha$ antibody on the prevention of lethal acute graft-versus-host disease in mice. Blood. 90:206a. (Abstr.)

47. Rus, V., A. Svetic, P. Nguyen, W.C. Gause, and C.S. Via. 1995. Kinetics of Th1 and Th2 cytokine production during the early course of acute and chronic murine graft-versus-host disease. J. Immunol. 155:2396-2406.

48. Lichtman, A., W. Krenger, and J.L.M. Ferrara. 1997. Cytokine networks. In Graft-vs-Host Disease, 2nd edition. J.L.M. Ferrara, H.J. Deeg, and S.J. Burakoff, editors. Marcel Dekker, Inc., NY. 179-218.

49. Fowler, D.H., J. Breglio, G. Nagel, M.A. Eckhaus, and R.E. Gress. 1996. Allospecific CD8+ Tc1 and Tc2 populations in GVL and GVHD. J. Immunol. 157:4811-4821.

50. Via, C.S., S.O. Sharrow, and G.M. Shearer. 1987. Role of cytotoxic T lymphocytes in prevention of lupus-like disease occurring in a murine model of graft-versus-host disease. J. Immunol. 139:1840-1849.

51. Sykes, M., V.S. Abraham, M.W. Harty, and D.A. Pearson. 1993. IL-2 reduces graft-versus-host disease and preserves a graft-versus-leukemia effect by selectively inhibiting CD4+ T cell activity. J. Immunol. 150:197-205.

52. Yang, Y., J.J. Sergio, D.A. Pearson, G.L. Szot, A. Shimizu, and M. Sykes. 1997. Interleukin-12 preserves the graft-versus-leukemia effect of allogeneic CD8 T cells while inhibiting CD4-dependent graft-versus-host disease in mice. Blood. 90:4651-4660.

53. Fowler, D.H., K. Kurasawa, A. Husebekk, P.A. Cohen, and R.E. Gress. 1994. Cells of the Th2 cytokine phenotype prevent LPS-induced lethality during murine graft-versus-host reaction. J. Immunol. 152:1004-1011.

54. Pan, L., J. Delmonte, C.K. Jalonen, and J.L.M. Ferrara. 1995. Pretreatment of donors with granulocyte colony-stimulating factor polarizes donor $\mathrm{T}$ lymphocytes toward type 2 cytokine production and reduces severity of experimental graft versus host disease. Blood. 86:4422-4429.

55. Bensinger, W.I., R. Clift, P. Martin, F.R. Appelbaum, T. Demirer, T. Gooley, K. Lilleby, S. Rowley, J. Sanders, R. Storb, and C.D. Buckner. 1996. Allogeneic peripheral blood stem cell transplantation in patients with advanced hematologic malignancies: A retrospective comparison with marrow transplantation. Blood. 88:2794-2800.

56. Schmitz, N., P. Dreger, M. Suttorp, E.B. Rohwedder, T. Haferlach, H. Loffler, A. Hunter, and N.H. Russell. 1995. Primary transplantation of allogeneic peripheral blood progenitor cells mobilized by Filgrastim (granulocyte colony-stimulating factor). Blood. 85:1666-1672.

57. Storeck, J., T. Gooley, M. Siadak, W.I. Besinger, D.G. Maloney, T.R Chauncey, M. Flowers, K.M. Sullivan, R.P. Witherspoon, S.D. Rowley, et al. 1997. Allogeneic peripheral blood stem cell transplantation may be associated with a high risk of chronic graft-versus-host disease. Blood. 90:4705-4709.

58. Neissner, M., and B.A. Volk. 1995. Altered Th1/Th2 cytokine profiles in the intestinal mucosa of patients with inflammatory bowel disease as assessed by quantitative reversed transcribed polymerase chain reaction. (RT-PCR). Clin. Exp. Immunol. 101:428-435.

59. Desreumaux, P., E. Brandt, L. Gambiez, K. Geboes, O. Klein, N. Ecters, A. Cortet, M. Capron, and J.F. Colombel. 1997. Distinct cytokine patterns in early and chronic ileal lesions of Chron's disease. Gastroenterology. 113:118-126.

60. Briscoe, D.M., L.E. Henault, C. Geehan, S.I. Alexander, and A.H. Lichtman. 1997. Human endothelial cell costimulation of T cell IFN- $\gamma$ production. $J$. Immunol. 159:3247-3256.

61. Nicholson, L.B., and V.K. Kuchroo. 1996. Manipulation of the Th1/Th2 Balance in Autoimmune Disease. Curr. Opin. Immunol. 8:837-842.

62. Strom, T.B., P. Roy-Chaudhury, R. Manfro, X.X. Zhen, P.W. Nickerson, K. Wood, and A. Bushell. 1996. The Th1/Th2 paradigm and the allograft response. Curr. Opin. Immunol. 8:688-693. 